\title{
LOCAL GOVERNMENT ROLE IN THE SOLVING OF CATCHING FISH ILLEGALLY IN ACEH REGION ${ }^{\Omega}$
}

\author{
Adwani, Mahfud, and Rosmawati \\ Law Faculty, Universitas Syiah Kuala \\ E-mail: adwani_fh@yahoo.co.id, mahfud.abdullah@yahoo.co.id, watie_sarah@yahoo.co.id
}

\begin{abstract}
This study aimed to describe the shape of local government actions in tackling illegal fishing in Aceh, the handling of illegal fishing destructive fishery resources. The fundamental point is Law No. 45 Year 2009 concerning fisheries. This spesification of this research descriptive analysis, used both normative juridical approach and empirical. The results showed that the local government has made an effort preventive and repressive in the case of illegal fishing. To coordinate with relevant agencies and empower the role of traditional institutions of the sea to assist the role of government and law enforcement.Local governments should improve the coordination and supervision of the marine area, to monitor and evaluate the performance of local authorities in applying the law against this illegal fishing case.
\end{abstract}

Keywords: Illegal, local government, and fishing.

\begin{abstract}
Abstrak
Penelitian ini dimaksudkan untuk menjelaskan bentuk tindakan pemerintah daerah dalam menanggulangi penangkapan ikan secara illegal di Aceh. Dasarnya adalah UU No. 45 Tahun 2009 tentang perikanan. Penelitian ini bersifat deskriptif analisis, dengan menggunakan metode pendekatan yuridis normatif dan empiris. Hasil penelitian menunjukkan bahwa pemerintah daerah telah melakukan upaya preventif dan represif dalam kasus illegal fishing. Melakukan koordinasi dengan instansi terkait dan memberdayakan peran lembaga adat laot untuk membantu peran pemerintah dan penegakan hukum. Hendaknya pemerintah daerah meningkatkan koordinasi dan pengawasan pada laut wilayah dan melakukan evaluasi terhadap kinerja instansi terkait dalam menerapkan hukum terhadap kasus illegal fishing ini.
\end{abstract}

Kata kunci: illegal, pemerintah daerah, dan penangkapan ikan.

\section{Introduction}

Indonesia as the world's largest archipelago nation considers the important of classical issues that are often encountered by many coastal States such as the problem of Illegal Fishing, so the issue becomes one of the focus of the Central Government in tackling the problems that hampered the progress of nation-building. Illegal fishing itself is a matter that has been around since the early inception of theory claims over the open sea and the close sea, until the birth of the modern international law of the sea $^{1}$ at this time. In addition, illegal Fishing is

$\Omega \quad$ This article is the result of research, Skim Strategis Nasional, funded by Directorate of Research for Community Service, Direktorat Dikti, according Letter of Agreement Implementation Research Grants for Lecturers of the biggest problem faced by many coastal States in advancing the economic society and the income of the State in the field of marine and fisheries. Indonesia in addition to losses resulting from fishing illegally or Illegal Fishing, as recorded in the data World Food Agency or FAO, Indonesia has recorded losses every year due to the Illegal Fishing of Rp 30 trillion. But the data was appraised the Minister of marine and Fishe-

college Batch I Unsyiah TA 2015 No. 035/SP2H/PL/Dit. Litabmas/II/2015, February 5, 2015.

See on Johanis Leatemia, "Pengaturan Hukum Daerah Kepulauan", Jurnal Mimbar Hukum, Vol. 23 No. 3, Oktober 2011, Yogyakarta: Faculty of Law, Uniuversitas Gadjah Mada; Melly Aida, "Penanggulangan Penangkapan ikan Secara Tidak Sah (Illagal Fishing) Oleh kapal Ikan Asing di Zona Ekonomi Eksklusif Indonesia", Fiat Justitia, Vol. 5 No. 2, May-August 2012, Lampung: Universitas Lampung. 
ries Susi Pudjiastuti is small enough, according to quantification, a loss of State resulting from Illegal Fishing, could reach US $\$ 20$ billion or Rp 240 trillion per year.

Cases relating to Illegal Fishing a lot going on in every area, no exception in Aceh. Geographically location of Aceh is very strategic and has the big enough potential of the sea, according to the data the land area of Aceh 57365.67 square $\mathrm{Km}$. While the water area reach 295,370 square $\mathrm{Km}$, which is composed of territorial waters and Islands $56563 \mathrm{sq} \mathrm{Km}$, as well as the waters of the exclusive economic zone (EEZ) of 238,807 square $\mathrm{Km}$. Sustainable potential is estimated at 272.7 thousand tons/year, the number of fishing vessel is 16701 units and the number of fishermen is 64466 people. ${ }^{2}$

Ocean as a part of Country's territory that has widest portion has to be used by Indonesia in order to keep country's sovereignty and make Indonesian citizen become prosperous ${ }^{3}$. Seeing the vast and the potential of the ocean in Aceh Province, so it is a common thing if the illegal fishing in Aceh is often happened, just like the case that is happened in East Aceh which is there are five fishing boats from Thailand that use trawl arrested by Indonesian Navy.

In order to solve the Illegal Fishing cases, there is International law that regulate named United Nations Convention on the Law of the Sea (UNCLOS) in 1982, the fish Protection set in article 61-64 as well as in Article 116 and article 117 UNCLOS 1982, and the International Law that regulate about fish protection in the exclusive economic zone and Biological Wealth Resource conservation. In Indonesia, there is a regulation in article 27 paragraph (1) of Law No. 45 Year 2009 concerning Fisheries that determines, oblige every person that has or operating the fishing boats with Indonesian Flag that is used when catching the fish in the area of fisheries management areas of the Republic of Indo-

2 Muzzakir, 2015, "Pengawasan Illegal Fishing di Perairan Aceh", Karya Ilmiah, Banda Aceh: Faculty of Law Universitas Syiah Kuala, page 2.

3 Eva Johan, "Pengukuran Lebar Laut Teritorial Menggunakan Garis Pangkal menurut UNCLOS 1982 dan Penerapannya dalam Hukum Indonesia", Vol. 9 No. 1, January 2009, Jurnal Dinamika Hukum, Purwokerto: Faculty of Law Universitas Jenderal Soedirman, page 40. nesia or high seas must own fishing license. Regard to article 5 of Law No. 5 Year 1983 concerning the Indonesia exclusive economic zone (EEZ) mentions that foreign ships held by the Treaty can be justified to catch fish in the EEZ. Therefore, if there is no permission, so the fisherman is not allowed to catch fish in the EEZ of Indonesia.

Paying attention on its settings, and be correlated in the context of autonomy, then, there is the regional authority (Regency/City) in the exploration, exploitation, conservation and management of fish resources wealth that is $\mathrm{i}$ mited to 4 nautical miles from the baseline. ${ }^{4}$ In this case, Local Government is required to play an active role to protect all the natural resources in their territory. Therefore, it needs a form of protection through a policy that was taken out in order to prevent and punish the perpetrators. It is interesting to be reviewed about the Government's role in solving illegal fishing in the waters of the sea of the Aceh province.

\section{Problems}

Based on the description above, then that becomes a problem in this writing as follows: first, how can the role of local Government in solving the catching fish illegally in water territorial of Aceh?; second, what are the constraints in solving fishing illegally in the waters of the Aceh region?; and third, what are the efforts conducted by local governments in solving fishing illegally in the waters of the territory of Aceh?

\section{Research Methods}

This research is a descriptive analysis, using methods of empirical, normative, and juridical approach. The data source in this research is the primary data and secondary data. Primary data obtained from field research done by interviewing the Rrespondents parties and informants that are associated with the object of this research.

4 Endang Sutrisno, "Implementasi Pengelolaan Sumber Daya Pesisir Berbasis Pengelolaan Wilayah Pesisir Secara Terpadu untuk Kesejahteraan Nelayan", Jurnal Dinamika Hukum, Vol. 14 No. 1, January 2014, Purwokerto: Faculty of Law, Universitas Jenderal Soedirman, page 3. 
As for who became informants and respondents as Head of Department of Marine and Fisheries province of Aceh, the head of the Department of Marine and Fisheries of North Aceh, Pidie, Aceh Barat(West Aceh), and Sabang each 1 person, Commander of the naval base (Danlanal) of Sabang and fishermen across regency/ city, and regency and city DPRK members. Data that has been received, either the primary data from field research, as well as secondary data obtained from Research Libraries that is tabulated and is generated which further will be analyzed qualitatively.

\section{Discussion}

The role of local Government in solving the Catching Fish illegally in territorial waters of Aceh

Local government has a major role in creating peace and the welfare of society. The existence of local governments is the primary goal of that is to improve the people's welfare in various aspects of life, including the marine environment, ${ }^{5}$ and the implementation of regional autonomy which is based on broad autonomy. In the region, there are the natural resources of the Sea (SDA). SDA is everything that consists in nature and used for the fulfillment of human necessity. SDA can be classified into two type they are: biological SDA and non biological such as petroleum natural gas such as various types of metal, water, and soil. ${ }^{6}$

In the territorial waters of Aceh, laot customary law forbids all kinds of tools that could damage the marine environment, such as bombing, poisoning, anesthesia, shocks, and so forth, ${ }^{7}$ including illegal way of catching fish and with the tools that are illegal. With operandi motives and modus, illegal fishing can be clas-

\footnotetext{
5 Husni Jalil, 2008, Hukum Pemerintah Daerah, Aceh: Syiah Kuala University Press, page 149.

6 Heryandi, "Kerjasama Internasional Pengelolaan Sea Bed Area dan Implikasinya bagi Negara Pantai", Jurnal Dinamika Hukum, Vol. 13 No. 3 September 2013, Purwokerto: Faculty of Law Universitas Jenderal Soedirman, page 358.

7 Sulaiman, “Kearifan Tradisional Dalam Pengelolaan Sumber Daya Perikanan di Aceh pada Era Otonomi Khusus”, Jurnal Dinamika Hukum, Vol. 11 No. 2 May 2011, Purwokerto: Faculty of Law Universitas Jenderal Soedirman, page 299.
}

sified as economic crime. This thing is very reasonable, for a general explanation in Law No. 31 Year 2004 changed with Law No. 45 Year 2009 concerning fisheries. ${ }^{8}$ Based on it, the illegal fishing case is a crime that needs to be given legal sanctions and needs arrangements in particular.

The role of local government in solving illegal fishing for a long time is a form of caring in conserving the source of wealth in the sea, but the role has been not seen effectively yet since there are still many cases of catching fish illegally. The head of the supervision of the Department of marine and Fisheries province of Aceh mention of local Government has been conducting preventive action, such as executing the activities of socialization on Illegal Fishing and fishing-related reporting mechanisms when foreign ships encountered. In addition, building cooperation with relevant institutions such as Navy, airud and others. As an example of the results of coordination was the arresting of foreign ships in East Aceh in April 2014 which arrest 4 people, i.e. one helmsman, four member of fishermen where two of them are Birma People and the rest are Thailand People?. Other forms of preventive supervision between the relevant institutions as carried out in the Lhoksemawe, North Aceh and East Aceh. However, the implementation of prevention refers to the Qanun Aceh number 9 Year 2010 concerning fishing, and it is not based on specific provisions related to such prevention efforts.

Other efforts that are done is conducting surveillance by naval police and Lanal. Lanal parties and the Marine and Fisheries Agency officers patrolling around, according to the schedule in an integrated manner with the Marine Police.

In order to carry out the role of local governments, the preventive action of illegal fishing carried out with integrated involve several

8 Yanti Amelia Lewirissa, "Praktek Illegal Fishing di Perairan Maluku Sebagai Tindak Pidana Ekonomi”, Jurnal Sasi, Vol. 16 No. 3 July-September 2010, Maluku: Universitas Pattimura, page 64 .

9 Interview result with Zulkarnaen, head of the supervision of the Department of Marine and Fisheries Aceh Province on May 13, 2015. 
related institutions, including the Laot Security Coordination Board (Bakorkamla). ${ }^{10}$ According to Miftahudin, the process of solving the problem of illegal fishing carried out by the Government which was played by the agencies-related institutions, in addition there is also the role of the fishermen by means of reporting to customs agencies of laot and Commander of laot then proceeded to Lanal and Airud or for following up. ${ }^{11}$ Practically, even though the process of prevention has been supported by a coordination system and provided by the tools of communication that is required, but that prevention has not been resulted in maximum results yet, especially in this case has not been regulating a specific set of countermeasures ${ }^{12}$. At the time of the interview with the DPRK of Pidie, stated that since 2009 to 2015 never produced Qanun about illegal fishing. Any local government parties have never proposed qanun draft about illegal fishing, and so far the DPRK has not received reports from the public related to illegal fishing by foreign fishermen. ${ }^{13}$

It is different with the results of interviews with Law Commission in DPRK of North Aceh, the DPRK said, there is already a related report on illegal fishing that occurred in the waters of North Aceh, but the discourse to formulate the law about illegal fishing has not been prioritized because there are other more urgent qanun related things. According to the DPRK of West Aceh party that so far has never discussed the qanun of illegal fishing, because there has been no qanun draft filed by local governments or DKP to DPRK. The DPRK essentially absorb the aspirations of fishing communities, but must understand the essence of the problem concerns the source of the wealth of fish in

10 Interview result with Siti Hasanah, Head of Transport Department of Transport Communication and Telecommunication Aceh Province on May 12, 2015.

11 Interview result with Miftahuddin, Laot Secretary Commander Aceh Province on May 12, 2015.

12 Interview result from the members of DPRA/DPRK from Sabang, Pidie, North Aceh, Meulaboh, East Aceh and Aceh Province, that there has never been born regulations related to illegal fishing either legislation in the Governor/regent and Aceh's qanun.

13 Interview result with Muhammad Ali, Chairman of legislature of DPRK Pidie on June 4, 2015. the sea. ${ }^{14}$ In addition to the DPRK, there is also the role of the DKP in the case of Illegal Fishing. For all this time, it has been done the DKP of provinces and Districts are hold related community reports illegal fishing and doing prosecution as well as to tackle illegal fishing, and uphold the law by arresting foreign ships, but the role of DKP is not optimal. The presence of symptoms of excess fishing, fish theft and other illegal fishing actions not only cause harm to the country, but also threatens the interests of fisherman, climate of industry, fish cultivator and national fisheries business. ${ }^{15}$

\section{The obstacles in solving illegal fishing in the} territorial waters of Aceh.

Obstacles that is faced by Government is in dealing with the cases of Illegal Fishing include: first, in General is there has not been the proper regulation of illegal fishing yet which strengthen the role of the Government and the apparatus itself in solving and overcoming a case of illegal fishing that occurred in Aceh. In these areas of research have relatively similar situations, both in the solving and finding solutions toward the cases of illegal fishing. The biggest obstacle is the existence of a regulatory region that has not yet been set up about illegal fishing. Local government in carrying out its tasks to the prevention of illegal fishing refers only to provisions that exist, because there has been no specific provisions set about solving fishing illegally. ${ }^{16}$ Second, the facility has not been adequately to monitor and there is no follow up toward the cases, such as ship control, communication tools, fuel and funds, personnel and transportation. In addition, that became an obstacle in solving illegal fishing because there is a community that does not immediately reported when seeing a case of illegal fishing. In fact, it is faced as an obstacle that sometimes

14 Interview result with $\mathrm{H}$. Bustan Ali, Chairman of legislature of DPRK West Aceh.

15 Maria Maya Lestari, "Penegakan Hukum Pidana Perikanan di Indonesia studi Kasus Pengadilan Negeri Medan", Jurnal Ilmu Hukum, Vol. 3 No. 2, 2014, Riau: Universitas Riau, page 273.

16 Interview result with Zulkarnen, head of the supervision of the Department of Marine and Fisheries Aceh Province on May 12, 2015 
there are reports from fishing communities, but not immediately be executed. ${ }^{17}$

Some other obstacles that are encountered that is occurred in Aceh or in areas such as Sabang, North Aceh, Pidie, and Melaboh. Based on the results of field research, it is found several factors that become an obstacle in solving the catching fish illegally in the area of territorial waters, which are: ${ }^{18}$ first, the lack of human resources. Lack of personnel in carrying out the task of supervision be a barrier to the internal factors in its countermeasures. Until now, the Department of Fisheries and Marine Resources only has 1 special police personnel, and some people who were undergoing education of Investigator civil servant. The lack of human resources (HR) in surveillance should be assisted with the support and the role of the fishermen. However, there may be challenged because of the level of education of fishermen is relatively very low, average traditional fishermen is educated low even some of them are still illiterate. ${ }^{19}$ It is indeed greatly affect performance and productivity of the fishermen. It is happened in Sabang, also in Melaboh that the on-site supervision and human resources is still very lacking in 1988, for example, rescue tools and radio as well as marine experts. ${ }^{20}$ Second, the operational costs. External factors faced by the marine and Fisheries Agency was the inadequacy of operational expenses given to the Department Marine and Fisheries to operate the patrol ship to control the ships that break the law of the sea. ${ }^{21}$

17 Interview result with Miftahuddin, Laot Secretary Commander Aceh Province on May 12, 2015

18 The data source from DKP in each research regency/city.

19 Andri Kurniawan, "Faktor-Faktor Yang Mempengaruhi Efektifitas Panglima laot Dalam Pengelolaan Sumber daya Alam Laut di Kota Sabang", Vol. 8 No. 3 September 2008, Jurnal Dinamika Hukum, Purwokerto: Faculty of Law Universitas Jenderal Soedirman, page 209.

20 Interview result with Syamsul Bahri, head of the supervision of the Department of Marine and Fisheries Melaboh on June 12, 2015.

21 Interview result with Zakaria, head of the supervision of the Department of Marine and Fisheries North on May 9, 2015.
Efforts are undertaken by local governments in solving fishing illegally in the waters of the territory of Aceh

For this time, these parties will mutually coordinate with the related parties regarding the cases of illegal fishing. As done by the Department of Marine and Fisheries (DKP) when the occured of a case of illegal fishing in the sea of East Aceh a few months ago, DKP is coordinating with apparatus such as Police Resort (Polres), Danlanal, Airud, fishermen, and Commander of laot and laot charmer. In addition, there are efforts made by Regent of Southweast Aceh (Aceh Barat Daya) by establishing an integrated supervisory patrol team with regent decree as mandated in the Ministerial Regulation No. 2 Year 2015 concerning the prohibition the use of Trawlers and Seine Net. The team pursues the coordination activities of the supervision, control and curbing capture tool that is not environmentally friendly in West Aceh Regency. Another task is to supervise the catching tool in the waters of West Aceh Regency, performing socializing and prosecution of legal for fishermen who use catching tool of fish that are not environmentally friendly and do destruction toward the catching tool.

As in Sabang, according to the Department of marine and Fisheries Sabang until now have not had a special effort in response to the arresting of illegal fishing, it is categorized that illegal fishing is a crime, then if it happened on 1-4-mile line was finished by customary courts named gampong based on consensus discussion or deliberation, and if it happens on the EEZ solved by Indonesian Navy based on positive law. In the contexts of non litigation, the Government also embrace lembaga adat laot for tackling this case, as well as authorize the commanders to do the reporting mechanism when case of illegal fishing occurs. Especially for Commanders of Laot. There is also the involvement of fishing communities in Aceh. Fishermen have a very important role in doing the reporting if there is illegal fishing. Efforts to solve illegal fishing is currently only done by law enforcement officers, citizen's involvement in solving illegal fishing only as informant. The pre- 
sence of Pokmaswas as an informant all this time received reports about the infringement of laot customary law, which then is followed up by Babinsa, Babinkatibnas and Indonesian Navy.

\section{Conclusion}

According to the analysis that is conducted, it can be concluded that: first, the role of local government in solvng illegal fishing is usually accompanied by a variety of devices/state apparatus such as the regional parties of lanal, Naval Police and others. But, cooperation and coordination among related parties has not occurred as effectively as it should. Second, constraints in solving illegal fishing, which is the lack of human resources that have special abilities. This is due to the recruitment of human resources system that is less suitable with the function that we need. Beside the human resources, there is an operational cost barriers and also availability of facilities such as communication tools and GPS. Third, efforts are being made in solving Illegal fishing by increasing cooperation among relevant institutions including involving indigenous institutions and fishing communities. Further training to community groups of Trustees through fishing communities were pioneered by commander of laot routine socialization and organized by DKP and local governments.

\section{Suggestions}

In the end, the author submits suggestions: first, local governments are expected to seriously solve catching fish illegally by foreign ships by improving coordination and supervision with embodies all the things that become an obstacle for this, for example: facilitating the team supervision in the sea with ships that are equipped with adequate communications equipment. So that, further the corporation can be improved between relevant institutions with streamline efforts regularly scheduled controls and pay attention to the equipment control or patrol vessels to offset the modern sophistication of fish to foreign vessels. Second, serious in cracking down on Illegal fishing perpetrators and soon gave birth to the rule model which is able to pose a deterrent effect for the perpetrators of illegal fishing. Third, adding to its human resources and increase the budget for its operation.

\section{References}

Aida, Melly. "Penanggulangan Penangkapan Ikan Secara Tidak Sah (Illagal Fishing) oleh kapal Ikan Asing di Zona Ekonomi Eksklusif Indonesia". Fiat Justitia. Vol. 5 No. 2. May-August 2012. Lampung: Universitas Lampung

Heryandi. "Kerjasama Internasional Pengelolaan Sea Bed Area dan Implikasinya bagi Negara Pantai". Jurnal Dinamika Hukum. Vol. 13 No. 3 September 2013. Purwokerto: Faculty of Law, Universitas Jenderal Soedirman;

Jalil, Husni. 2008. Hukum Pemerintah Daerah. Aceh: Syiah Kuala University Press;

Johan, Eva. "Pengukuran Lebar Laut Teritorial Menggunakan Garis Pangkal menurut UNCLOS 1982 dan Penerapannya dalam Hukum Indonesia". Vol. 9 No. 1. January 2009. Jurnal Dinamika Hukum. Purwokerto: Faculty of Law, Universitas Jenderal Soedirman;

Kurniawan, Andri. "Faktor-Faktor yang Mempengaruhi Efektifitas Panglima Laot dalam Pengelolaan Sumber Daya Alam Laut di Kota Sabang". Vol. 8 No. 3 September 2008. Jurnal Dinamika Hukum. Purwokerto: Faculty of Law Universitas Jenderal Soedirman;

Leatemia, Johanis. "Pengaturan Hukum Daerah Kepulauan". Mimbar Hukum. Vol. 23 No. 3. Oktober 2011. Yogyakarta: Faculty of Law, Universitas Gadjah Mada;

Lestari, Maria Maya. "Penegakan Hukum Pidana Perikanan di Indonesia studi Kasus Pengadilan Negeri Medan". Jurnal Ilmu Hukum. Vol. 3 No. 2. 2014. Riau: Universitas Riau;

Lewirissa, Yanti Amelia. "Praktek Illegal Fishing di Perairan Maluku Sebagai Tindak Pidana Ekonomi”. Jurnal Sasi. Vol. 16. No. 3 July-September 2010. Maluku: Universitas Pattimura;

Muzzakir. 2015. "Pengawasan Illegal Fishing di Perairan Aceh". Karya Ilmiah. Banda Aceh: Faculty of Law Unsyiah; 
Sulaiman. "Kearifan Tradisional Dalam Pengelolaan Sumber Daya Perikanan di Aceh pada Era Otonomi Khusus". Jurnal Dinamika Hukum. Vol. 11 No. 2 May 2011. Purwokerto: Faculty of Law Universitas Jenderal Soedirman;

Sutrisno, Endang. "Implementasi Pengelolaan Sumber Daya Pesisir Berbasis Pengelolaan Wilayah Pesisir Secara Terpadu untuk Kesejahteraan Nelayan". Jurnal Dinamika Hukum. Vol. 14 No. 1. January 2014. Purwokerto: Faculty of Law Universitas Jenderal Soedirman. 